\title{
Active Teaching Approach: Teaching and Learning Methods on Historical and Cultural Theory
}

\author{
Maria Eliza Mattosinho Bernardes \\ College of Arts, Sciences and Humanities (EACH), University of São Paulo, USP Leste, São Paulo, Brazil \\ Email: memberna@usp.br
}

Received 28 October 2013; revised 20 December 2013; accepted 5 January 2014

Copyright (C) 2014 by author and Scientific Research Publishing Inc.

This work is licensed under the Creative Commons Attribution International License (CC BY).

http://creativecommons.org/licenses/by/4.0/

(c) (i) Open Access

\begin{abstract}
This study is a theoretical synthesis of researches performed in the scholar context aiming to present an active teaching and learning proposal that sees teaching approach as the dialectical unity in concepts of internalization movement. The actions are organized by the professor and carried out by the subjects who are actively involved in the educational process. The field research is based on the assumptions of dialectical and historical materialism, historical and cultural psychology and the action-research. In the theoretical field, the study shows the theoretical and methodological principles of the pedagogical activity and characterizes the triggering situation, the ways of action in the study community, and the means of learning control as the structure of the activity in common existing in the teaching-learning relationship. The results show the teaching organization based on school reality which aims, through the processes of questioning reality and mediating historically elaborated knowledge, to lead the subjects involved in pedagogical activities to the comprehension of what is real and to the development of human potential.
\end{abstract}

\section{Keywords}

Historical-Cultural Psychology, Educational Activity, Active Methodology

\section{Introduction}

Identifying teaching and learning as activities requires the recollection of this concept from the dialectical and historical materialism and from the historical and cultural psychology. Leontiev (1983) identifies that the activities must be performed by several subjects integrated in a collective group. The actions and operations, constituent parts of the activities, must be targeted to a purpose which aims the production of tools that may provide a 
better relationship between the motive and the goal of the activity. It is considered, therefore, that the activity is addressed to a purpose to be achieved by all collectivity subjects.

Regarding the pedagogical activity, understood as the dialectical unity between teaching and learning (Bernardes, 2006), the relationship between the motive (the need for humanization through the access to human elaborations) and the activity objective (teaching and learning of culture elements elaborated by literate society) presupposes that tools should be produced by the subjects involved in the activities in order to enable its objectification in the concrete reality.

The meaning of pedagogical activity regarding historical and dialectical materialism particularized in the educational dimension existing in the relationships between teaching and learning generally treated by cultural-historical psychology, takes into account that the school is a social institution with the purpose of teaching historically knowledge developed by a group of people and mediated in the school context in a systematic and well organized way. In this dimension, the pedagogical activity should provide teaching conditions that enable students to engage in study activities, aiming to lead them to achieve a knowledge that is not part of the daily life, the scientific knowledge.

Asbahr (2005) indicates that as social meaning of the pedagogical activity, the students' formation of critical thinking enables them to access the production process of the historically elaborated knowledge. In this point of view, the student is not only the teacher's object of activity, but he/she takes over the function of subject of his/ her own activity, establishes him/herself in the teaching/learning activity by actively and intentionally participating of the knowledge appropriation process, overcoming the spontaneous and customary way of learning.

It is conceived, therefore, that the pedagogical activity must be understood, according to the dialectical conception, as the one which promotes changes of circumstances in the man himself in a simultaneous way. According to Vázquez (1977: p. 160), “[...] this unity between circumstances and human activity or between the transformation of circumstances and the self-transformations of the man is only verified in and for revolutionary practice" ${ }^{\prime 1}$. The dialectical unity of transformation of man and circumstances are identified by the author as revolutionary praxis.

From this theoretical conception, the pedagogical activity as revolutionary praxis considers some dialectical principles proper to the historical materialism such as: "a) not only men are product of circumstances, but the circumstances are equally their products. [...] b) educators should also be educated. [...] c) the circumstances that modify men are, at the same time, modified by them.”2 (Vázquez, 1997: pp. 159-160).

As a theoretical and methodological tool of the praxis, the pedagogical activity must synthesize the needs existing in the individual's constitution, a fact that specifies the constituent elements of pedagogical activity structure: the triggering-situation, the ways of action and the "learning control" (Bernardes, 2006).

\section{Constituent Elements of Pedagogical Activity}

Considering that the purpose of pedagogical activity is the transformation of the subjects' constitution by means of the relationship between teaching and learning of historically and culturally produced elaborations, it must be considered that not every triggering situation satisfies the initial condition of triggering situations of reflection that enables the students' development of theoretical thinking. It is considered that such situations shall be resultant from the practical activity as derived from the relationships between men and objective reality and its implications in the pedagogical process. The triggering situation, in these circumstances, is identified as the dialogical movement starting point about the concepts to be studied in the pedagogical activity and it is the expression of social practices widely ${ }^{3}$ instituted in society.

Being the triggering situation of dialogical movement of the concept the one that creates possibilities to the social practices problematization, it is considered relevant to explicit the particularities of practical and theoretical problems. Rubtsov (1996) emphasizes the difference between the concrete practice problems and the learning problems, also identified as theoretical problems, with the first two not being able to enable the overcoming of the knowledge that exceeds the empirical experience, as they also don't contribute to the learning of theoretical contents. The second type of problem relates to a particular form of cognitive action that characterizes the way of analyzing the study object; by means of specific actions execution, it is possible to identify the

\footnotetext{
${ }^{1}$ Free translation.

${ }^{2}$ Free translation.

${ }^{3}$ The theoretical conception here presented approximates the assumption of revolutionary pedagogy proposed by Demerval Saviani (2008) in his essay Escola e Democracia II: paraalém da teoria da curvatura da vara.
} 
concept principles and proprieties, allowing the appropriation of theoretical knowledge.

The characterization of the two types of problem presented by Rubtsov (1996) relates to the considerations by Davidov $(1982,1988)$ who affirms that the teaching method that aims the appropriation of the concept's essence enables the students theoretical thinking development, and the teaching method that only enables the appropriation of concept's external characteristics doesn't enable the overcoming of empirical thinking.

The particularities of theoretical and practical problems identified by the authors are considered in this study as non-eliminable from the triggering situation of the concept's dialogical movement to be developed in the pedagogical activity as revolutionary praxis, however, it becomes necessary to explicit other elements constitutive of the triggering situation in the pedagogical activity. The triggering situation must contain the "historicity and the internal nexus" of the concept to be studied and it must represent a need for investigation to the students, mobilizing them to execute study actions. It is considered that these conditions are essential in the organization of teaching, because they create opportunities for the educator and the student to appropriate the concept as a product of human activity, fundamental fact to overcoming the alienating conditions existing in school education, starting from the way it is structured, as well as in contemporary society.

With regard to the educator, he/she must study the concept that will be contemplated in the teaching organization, appropriate the process of historical production of the concept itself, (re)formulate the concept, summarizing it in a triggering situation which solution contains its essence, and he/she must also create intentional and conscious ways of action in the pedagogical activity to enable students to appropriate the theoretical concept.

The appropriation of the historical-cultural knowledge by the activity subjects and the movement derived from their transformation are considered mediating elements between the ontological dimension of the person's constitution and the praxis in the pedagogical activity. The "theoretical knowledge mediation" is considered essential to the teaching organization by the definition of its actions and operations in pedagogical activity, since it is due to the appropriation of those concepts that the educator defines the way of action and the learning control to be established in the teaching and learning process in school context.

The way of action is initially identified by Bernardes $(2000)^{4}$ as being part of the organization of practical actions of teaching orienting activity, as a pedagogical tool elaborated by Moura (1992). Throughout the decades, this tool has been appropriated and developed by researchers of Studies and Research Group on Pedagogical Activities-GEPAPE-on the development of new researches in scholar field. The group's current studies identify the concept of teaching orienting activity as a theoretical-methodological tool that mediates the teaching organization taking as reference the theory of activity and the historical-cultural focus. In more recent studies (Bernardes, 2006, 2012), the ways of action started being considered as a possibility of organization of the practical actions in the interpersonal relationships and in pedagogical activity teaching organization.

In the context of pedagogical activity as revolutionary praxis, the "ways of action" refer to the set of actions and operations to be performed by the subjects in shared situations. The concept definition is based on the conceptions of "activity in common" by Rubtsov (1996) and of the organization of this activity identified by Rivina (1996) as the "set of efficiency factors". In researches on the need to consider the set of efficiency factors in the activity in common in school context, Rivina (1996) concludes that teaching procedures which make 6-10-yearold children participate in teaching situations that promote occasional learning in the process of thinking about certain knowledge, "[...] can take the majority of our students to school failure. [...] The learning success of young students depends, largely, on the form assumed by the activities to which they engage in community." (Rivina, 1996: p. 150).

Empirical studies performed in school context (Bernardes, 2000, 2006), show the different aspects of the organization of the pedagogical activity that aim the theoretical concepts appropriation by the students. These studies are based on the propositions by Rubtsov (1996) on the activity in common, which forecasts: 1) the division of actions and operations; 2) the exchange of ways of action; 3) mutual comprehension; 4) communication; 5) planning of individual and collective actions; and 6) reflection. It is also considered the importance attributed by Rivina (1996) to the ways of organization of the activity in common, which considers: 1) the students positioning inside the classroom and 2) the distribution of the operations related to objects and contents of the activity.

The need to consider the physical, social and methodological aspects in the definition of the ways of action that organize the relationships between teaching and learning is identified in the empirical studies on the praxis in the pedagogical activity.

As for the physical aspect, the need to organize the space in which teaching and learning actions take place is

${ }^{4}$ It relates to theoretical elaborations produced in the research-action performed in the initial series of basic education. 
indicated, considering the acoustics of the place in which it occurs and the visibility of the actions by the subjects that are participating in the pedagogical activity. The fact of not considering these elements in the physical organization of teaching organization can hinder the development of the actions and operations in social and methodological aspects, since it prevents the fulfillment of interpersonal relationships, compromising the teaching and students learning.

Regarding the social aspects, it is identified the necessity of structuring the interpersonal relationship of the subjects involved in the pedagogical activity, aiming to share the control of actions and operations between the educator and the students. This procedure aims to assign responsibilities and to share functions between subjects in the pedagogical activity (Bernardes, 2006).

The shared actions (Bernardes, 2000, 2006) occur in the empirical studies in two different moments: initially, the actions are performed in small groups and, later, between all subjects in a collective way. This procedure is established in the organization of interpersonal relationships for all students to actively participate in the movement of reflection on the concept. Therefore, specific functions to be accomplished by the subjects in the educational activity are defined, having in mind the classification of agents of social control.

To do so, a micro-organization is established in the active students group, having in mind the necessity of maintaining the sharing of actions (Rubtsov, 1996), the control and the evaluation of actions performed in the activity (Davidov, 1988; Davidov \& Markova, 1987). The implementation of these actions aims to create conditions for the subjects in activity to be responsible for the actions in the study collectivity (small groups and classgroup) and to be aware of the functions they execute in shared moments of study.

The following Table 1 presents the social functions in the organization of small study groups in pedagogical activity.

When identifiyng the functions of the timekeeper, organizer, spokesperson, draftsman to be fulfilled by the students on the small study groups, the empirical studies here mentioned highlight that such functions must alternate between the participants of the student group so that everyone can experience the different control situations in the interpersonal relationship of the pedagogical activity. The function performed by the educator fulfills the determination of the meaning of his/her social place as a teaching organizer so that the theoretical knowledge is mediated in the school context.

After the small group study stage, the students start acting in the class-group, in a collective way, reflecting on the elaborations initially produced. It is a matter of actions that promote the critical analysis of students' production in small groups by the dialogical process provided by the educator. Such actions are made possible by the communication process between subjects and they promote students learning control situations by both the educator and the students, because they have the opportunity to reflect on the product of their own actions, through teaching, studying and the actions of other students of the class-group.

The actions of collective reflection, both in small groups and in class-groups should be guaranteed by the intervention of the educator to make it possible to overcome the initial elaborations of the students towards the theoretical concept. Such interventions occur in the field of oral and written language and should be defined from the educator's awareness (Bernardes, 2012) of the internal concept nexus and of the manifestations of students learning through oral and written language.

\section{Table 1. Systematization of the subjects functions in small study groups.}

\begin{tabular}{|c|c|}
\hline \multicolumn{2}{|r|}{ Microorganization: Study Group } \\
\hline Subjects & Place in Group \\
\hline $\begin{array}{l}\text { Timekeeper } \\
\text { (student) }\end{array}$ & To control time during the activity’s development. \\
\hline $\begin{array}{l}\text { Organizer } \\
\text { (student) }\end{array}$ & $\begin{array}{l}\text { To make sure that the actions between students are suitable for the development of the study activity, } \\
\text { by organizing them. }\end{array}$ \\
\hline $\begin{array}{l}\text { Spokesperson } \\
\text { (student) }\end{array}$ & To communicate to the class-group the elaborations and reflections of their study group. \\
\hline $\begin{array}{l}\text { Draftsman } \\
\text { (student) }\end{array}$ & To organize the students elaborations during the reflection movement, by registering them. \\
\hline Teacher & To mediate the knowledge in the concepts internalization movement. \\
\hline
\end{tabular}


The fact that the students perceive themselves as participants of a study collectivity, either in small and/or class-groups enables them to become aware of the importance of cooperative actions in shared studies. The student's developed consciousness of the fact that they belong to a study collectivity is due to the fact that the existing relationship between the ways of actions performed by the students correspond to their action's meaning in the study activity. The student's consciousness formation (Bernardes, 2012) as for the participation in study collectivity is crucial for them to identify the collective elaborations produced in the concept dialogical movement and to appropriate the same activities. These are actions and operations in the constituent movement of students' "conscious learning” (Leontiev, 1983) and, while students appropriate the concept's social-historical conditions, they also perceive themselves as active subjects aware of the individual and collective actions that allow them appropriating the knowledge (re)produced in the study collectivity.

This is a matter of the knowledge internalization movement defined by Vigotski (1999, 2001a, 2001b) as constitutive of higher psychological functions through the interpersonal relationships, highlighted in the intrapersonal relationships by learning manifestations. Leontiev (1983: p. 79) emphasizes the specificity of the concept by stating that "[...] the internalization process consists not of the fact that the external activity is introduced in an internal 'conscience domain'; the internalization is a process in which this internal domain is precisely formed." The meaning of the internalization process explained by Leontiev is decisive for the comprehension of the constitution of subjects of a study collectivity. The knowledge internalization process arising from mediations between the existing inter and intrapsychological aspects identified by Vygotsky and Leontiev, is highlighted in the dialogical movement of the concept in different stages of the organization of the subjects' actions in the pedagogical activity.

In the dialogical process of the concept, the student's personal elaborations appropriated in previous learning situations (intrapsychic manifestations) and set in reflection movement in the small study groups are turned into collective elaborations (interpsychic manifestations). By the time the small groups' collective elaborations are set in reflection movement in the study collectivity, they are again (re)elaborated, exceeding the initial conditions through the mediations of the theoretical knowledge promoted by the educator. By the collectively elaborated knowledge synthesis process, the students appropriate the knowledge produced in the collectivity and start using it in their personal relationships (intrapsychic manifestation). This process is constitutive of the subjects' subjectivity, once it is by the internalization of interpersonal elaborations that the individual's internal domain (intrapersonal) is formed.

The appropriation of knowledge described as a product of the knowledge internalization movement in pedagogical activity shows the (inter) intra-inter-intrapsychic plan, according to the conceptualization previously elucidated by Leontiev (1983).

That plan doesn't consider that the starting point of the knowledge internalization process is the individual's personal production, quite the contrary. The starting point is the knowledge developed among men historically and culturally involved in a collective activity, which, in turn, is mediated and appropriated by the subjects in their interpersonal relationships. The knowledge appropriated by individuals is manifested by oral or written language as an intrapsychic manifestation in pedagogical activity, and it will again be set in reflection movement in a context of study, and it will be (re)elaborated through symbolic mediations related to the theoretical concept. Once the knowledge is appropriated by the subjects, now in a new quality, it becomes a part of the subject's relationships and it will be manifested in the intrapsychic relationships as a thought and through the communication process. However, the concept appropriation does not occur naturally or spontaneously in the relationships between subjects. Specific actions are necessary for the phenomenon to be objectified.

The organization way of the interpersonal relationships in the concept internalization movement is identified as the methodological aspect of the pedagogical activity. In the organization of interpersonal actions three different stages are identified: 1) the concept contextualization; 2) the dialogical process of the concept; 3) the manifestation of the concept appropriation (Bernardes, 2000, 2006). The following Figure 1 registers the organization of the actions between the subjects of the pedagogical activity in the concept internalization movement starting from the interpersonal relationships (small groups and intergroup) in the pedagogical activity.

In the initial stage of the learning organization, named concept contextualization, the interpersonal actions occur aiming to bring back the knowledge previously appropriated by the students (intrapsychic manifestations) that refers to the theme existing in the triggering situation of the teaching and learning process that shall contain the internal nexus of the concept to be appropriated by the students. That triggering situation is based on social ${ }^{5}$ Free translation. 


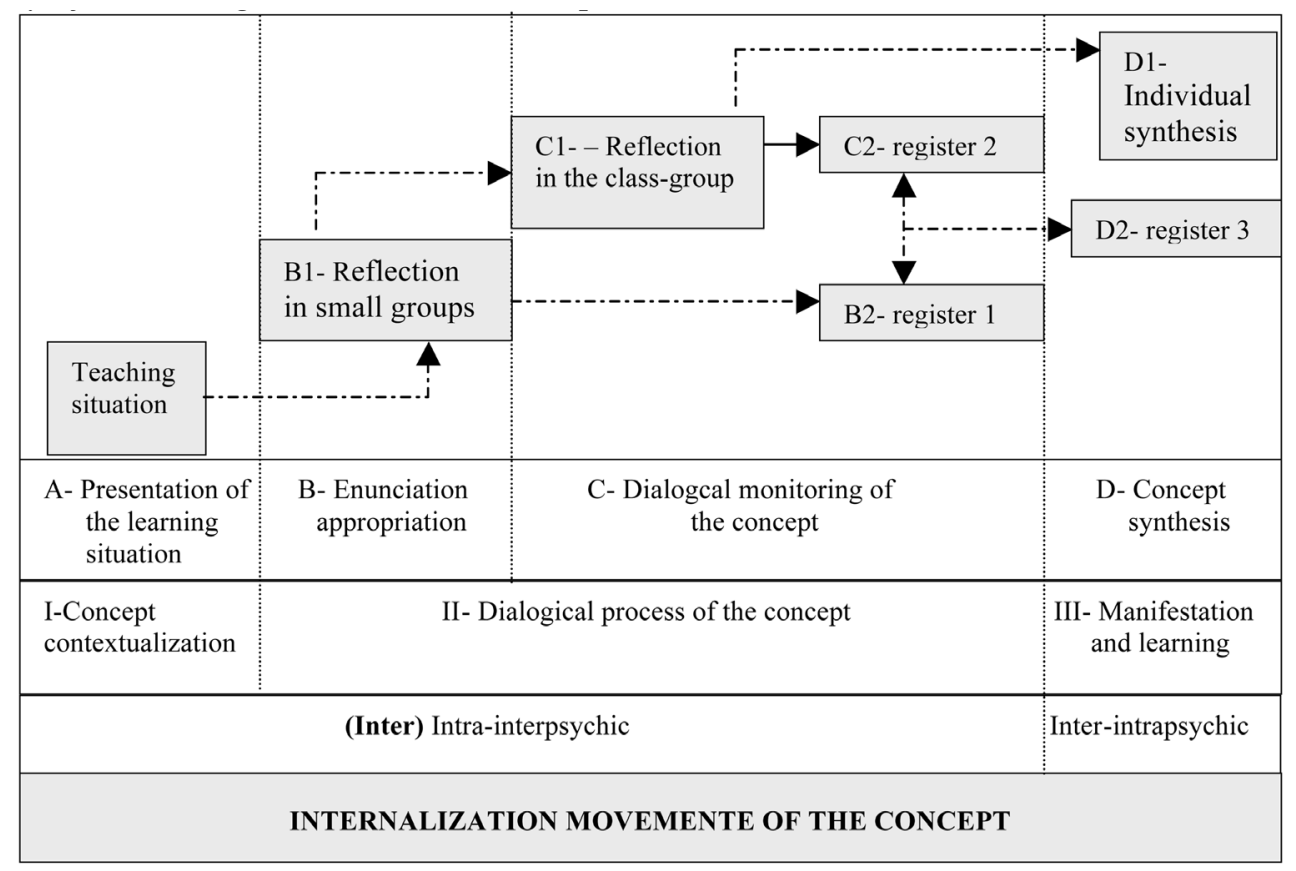

BERNARDES (2006. p. 136).

Figure 1. Way of action organization in the concept internalization movement.

practices and it represents a social or personal need, once its function is to mobilize the students in order to perform study tasks, study actions and learning control and evaluation. In this organization stage the presentation of the learning situation (A) occurs when the students are integrated to the study colletivity.

The stage of the teaching organization that promotes the development of study and teaching actions is identified as a dialogical process of the concept. The pedagogical intent of this stage is to promote a reflection on the situation to be investigated by students, recording the different situations of understanding study object. The students' actions are performed collectively and move between manipulation situations on the subject matter and situations of communication and mediation of the concept in the movement of arguments and counter-arguments about the knowledge in question. The dialogical process, according to the teaching organization presented, is divided into two characteristic segments: the appropriation of the enunciation (B) and the dialogical monitoring of concepts (C) (Bernardes, 2000, 2006).

The enunciation appropriation occurs under the organization of the subjects' actions in small study groups. This stage may be accomplished in any scholar situation; however, with children in the early stages of education, it makes it possible for the students not to drift away from the learning situation proposed, creating conditions to all students to be engaged in the reflection process. It also allows the students to interact "with each other", aiming to better understand the teaching situation to be investigated; moreover, it allows the knowledge already appropriated by the students (intrapshychic manifestations) to be retreated and negotiated in the small study groups. This moment is characterized as a stage in which the students understand the complexity of the situation to be investigated in the teaching and learning actions, a fact not always identified in the previous stage, the presentation of teaching situation. As a result of the elaborations and reflections of the small study group, there is the production of a collective register (register 1-interpshychic manifestation) that highlights the first manifestation of concept appropriation by the students.

The actions of dialogical monitoring of the concepts correspond to the moments in which the students show their first elaborations on the concept, which are registered by the small study groups, problematized by the mediating action of the educator and collectively reflected between all students (class-group reflection). The pedagogical intention of this moment is to create conditions for the students to know the elaborations of the other students and to expand their considerations on the concept studied. It is observed in moments in which the small study groups' registers are presented that the educator's intervention is fundamental to the organization of the students' thought so it gains a greater complexity. In this teaching organization stage the concepts acquire a 
greater profundity and magnitude, achieving more elaborated conceptual levels. After the intergroup reflection a new individual and/or collective register is produced (register 2-interpsychic manifestation), that represents a new level of complexity in the concept appropriation. This stage of the ways of action set shall be expanded, as often as necessary, so the student may overcome the empirical dimension of the concept, achieving theoretical levels in the learning manifestations.

According to the way of action existing in the dialogical process of the concept, the collective action aims to share actions and functions to be performed by the subjects of the pedagogical activity. In this process, the intrapersonal elaborations are valued in the production of interpersonal elaborations as singular contributions to the appropriation process of the theoretical concept.

Through the interventions to be accomplished by the educator in oral and written language field, the personal sense manifested by the students in the appropriation of the concept gets close to the social meaning of the study object-the theoretical concept. In this process, the contributions of all collectivity study participants occur when the interpersonal elaborations assume a magnitude and a complexity different from the previous elaborations, reaching inaccessible levels of theoretical elaboration. Once the collective production is appropriated by the students in the concept internalization movement, the psychological functions of the students are constituted in a new dimension, identifying the development process of the superior psychological functions in the pedagogical activity.

Another aspect present in the way of action proper to the dialogical process of the concept is the cooperative action between the subjects of the pedagogical activity, when the action and operation control is shared between educator and students. It is the understanding that all subjects of the pedagogical activity are accomplices in the teaching and learning process. In order to achieve the purpose of collective activity in the practice, it is necessary to share the control of actions and operations in pedagogical activity, as well as the evaluation of teaching and learning process by all subjects integrated to the study collectivity.

As a result of the ways of action characterized in the dialogical process of the concept, the valorization of the collective and corporative actions in the pedagogical activity is viable as well as their importance to the development of each of the subjects, promoting the mutual respect between students and between the educator and the students.

The learning manifestation actions existing in the concept internalization movement occur in several moments of the pedagogical activity, however, by the end of the dialogical process of the concept, a specific moment is identified in which the students produce individual registers (register 3-intrapsychic manifestation) expressing, by different ways of communication (oral, written, pictorial and gestural) the concept appropriation. This representation of the concept manifests its level of comprehension by the student in an individual way (intrapsychic manifestation) that indicates the appropriation of the concept by each of the study collectivity students.

Under different manifestations of students learning, the educator (re)structures the actions in the teaching organization, aiming the quality changes in the concepts appropriation. The analysis processes of the different manifestations of students learning and the reorganization of teaching that aim to promote changes in the concept appropriation by the students, characterize the learning control situations by the educator and the students in the pedagogical activity.

\section{Some Considerations}

The ways of action of the pedagogical activity constitute the objective conditions of the pedagogical activity as a dialectical unity that integrates the teaching and learning actions in an active way both by the educator and the students. As a substantial element of the praxis in the pedagogical activity, which enables the creation of conditions favorable to the development of the students' theoretical thinking, the collective and cooperative actions and operations between subjects assume particularities in cognitive, volitional and affective aspects (Bernardes, 2006, 2012; Bernardes \& Moura, 2009).

As for the cognitive aspect, besides considering the interpersonal actions resulting from the collective and cooperative reflection process, it institutes the need to consider the dialogical movement of the concept that reveals the mediation between the object's social meaning and the personal meaning expressed in the students particular elaborations.

As for the volitional aspect, differentiating elements are identified, which contribute for the students to be 
ready and willing to perform tasks and actions of study, considering their awareness of being part of a study collectivity. In this respect, it emphasizes the division of functions between the subjects of pedagogical activity and of learning control among them, helping educators and students to make commitments for the purpose of pedagogical activity.

The affective aspect between the pedagogical activity members assumes the condition of being the amalgam that integrates with the volitional and cognitive aspects in collective and cooperative actions and operations. It is significant to emphasize the importance of respect and appreciation of the conceptual actions and elaborations of each of the subjects of the study collectivity. However, the need to consider the relationship between individual elaborations and the group-class collective production is identified. It is necessary to emphasize the need of the study collectivity to get contributions from all subjects of the pedagogical activity in order to produce broader and more complex elaborations, valuing the interpersonal dimension in the constitution of the subject's intrapersonal dimension.

As for the learning organization, this didactic and pedagogical tool is one of the products in the educator's activity that is objective in the teaching action organization aiming the conscious learning by the students. Those specific conditions identify some aspects that make the actions and operations of educators and students a revolutionary practical activity for creating conditions that allow the transformation of them both.

The conscious learning requires the students' actions to be mobilized by the relationship between the meaning and the learning activity meaning beyond the necessity of considering the internal and external relationships existing in the study object elaboration. The internal nexus of the concept elaborated throughout its historicity should be considered, as well as the connections that it has with human relations in general must be taken into account. It's been said that starting from the appropriation process of human elaborations historically constituted-the concepts-the transformation of the individuals' constitution, students in general, becomes possible.

The teaching organization that enables the creation of appropriate conditions for the occurrence of conscious learning by students is predominant so that the purpose of the pedagogical activity becomes objectified in the teaching and learning process. The objectification of the relationship between the motive and purpose of the pedagogical activity through the actions and operations performed by the educator and by the student is identified, according to the various authors of the cultural-historical theory, as well as activity geared to teaching and learning.

In this respect, the awareness of the educator regarding the social place he/she occupies in society and the real teaching possibilities in promoting the transformation of the constitution of individuals is crucial for the performance of actions and operations in the teaching organization objectified in the learning of historically elaborated knowledge and in the development of students' psychological functions.

\section{References}

Asbahr, F. da S. F. (2005). Personal and Political-Pedagogic Sense: Analysis of the Pedagogical Activity from Historic-Cultural Psychology (Sentido pessoal e projeto político pedagógico: Análise da atividade pedagógica a partir da psicologia histórico-cultural). Thesis (Masters in Psychology and Human Development), São Paulo: Psychology Institute of São Paulo’s University.

Bernardes, M. E. M. (2000). The Actions Regarding Learning Activities (As açõesnaatividadeeducativa). 2000. $201 \mathrm{f}$. Thesis (Masters in Education), São Paulo: College of Education, São Paulo’s University, São Paulo.

Bernardes, M. E. M. (2006). Symbolic Mediations Regarding Pedagogical Activity: Historic-Cultural View's Contribution to Teaching and Learning. (Mediações simbólicas na atividade pedagógica:contribuições do enfoque histórico-cultural para o ensino e aprendizagem). 2006. 330f. Thesis (Doctors in Education), São Paulo: College of Education, São Paulo’s University.

Bernardes, M. E. M., \& de Moura, M. O. (2009). Symbolic Mediations regarding Pedagogical Activity. Educationand Research, 35, 463-478. http://dx.doi.org/10.1590/S1517-97022009000300004

Bernardes, M. E. M. (2012). Pedagogy and Pedagogical Mediation (Pedagogia e mediação pedagógica). In J. C. Libâneo, \& N. Alves (Eds.), Pedagogy Topics: Dialogs between Teaching Methods and Curriculum (Temas de pedagogia: diálogos entre didática e currículo) (pp. 77-97). São Paulo: Cortez.

Davidov, V. V. (1988). The Teaching Method and the Psychic Development: Theoretical and Experimental Psycholocal Investigation (La enseñanza escolar y el desarrollopsíquico: Investigaciónpsicológicateórica y experimental). Moscou: Progresso.

Davydov, V., \& Markova, A. (1987). The Conception of the Activity of the School Studio (La concepcion de la actividad de 
studio de los escolares). In V. Davydov, \& M. Shuare (Eds.), Evolutionary Psychology and Pedagogy in the USSR: Anthology (La psicologia evolutiva y pedagogia en la URSS: Antologia). Moscow: Editorial Progresso.

Leontiev, A. N. (1983). Activity, Conscience, Personality (Actividad, conciencia, personalidad). Habana, Cuba: Pueblo y Educación.

de Moura, M. O. (1992). The Building Process of a Numeric Sign into a Teaching Environment (A Construção do signo numérico em situação de ensino). Thesis (Doctors in MathsMethodology), São Paulo: College of Education, São Paulo’s University.

Rivina, I. (1996). The Collective Activity's Organization and the Cognitive Development between Young Children (A organização de atividades coletivas e o desenvolvimento cognitivo em crianças pequenas.) In C. Garnier, N. Bernarz, \& I. Ulanovskaya (Eds.), After Vygotsky and Piaget: Social and Constructive Russian and Western Schools' Perspectives. (Após Vygotsky e Piaget: perspectivas social e construtivista escolas russa e ocidental) (pp. 138-150). Porto Alegre, RS Artes Médicas.

Rubtsov, V. (1996). The Learning Activity and the Problems Reffering to Students' Theoretical Thinking Development (A atividade de aprendizado e os problemas referentes à formação do pensamento teórico dos escolares). In C. Garnier, N. Bernarz, \& I. Ulanovskaya (Eds.), After Vygotsky and Piaget: Social and Constructive Russian and Western Schools' Perspectives (Após Vygotsky e Piaget: perspectivas social e construtivista escolas russa e ocidental) (pp. 129-137). Porto Alegre, RS: Artes Médicas.

Saviani, D. (2008). School and Democracy (Escola e democracia). Commemorative Edition. Campinas, SP: Associated Authors.

Vázquez, A. S. (1977). Praxis’ Philosophy (Filosofia da práxis) (2nd ed.). Rio de Janeiro, RJ: Paz e Terra.

Vigotski, L. S. (1999). Childhood’s Psychological Development (O desenvolvimento psicológico na infância). São Paulo: Martins Fontes.

Vigotski, L. S. (2001a). Pedagogical Psychology (Psicologia pedagógica). São Paulo: Martins Fontes.

Vigotski, L. S. (2001b). Collected Works (Obras escogidas). Madrid: Machado Libros v.2. 